\title{
Simplified quantitative methods for bacteriuria and pyuria
}

\author{
JAMES MCGEACHIE AND ARTHUR C. KENNEDY \\ From the University Departments of Bacteriology and Medicine, \\ Royal Infirmary, Glasgow
}

SYNOPSIS Although pyelonephritis is a common disease, it escapes clinical detection in an un-? desirably high proportion of patients. The present unsatisfactory diagnostic position would be much improved by widespread screening of patients by simple yet reasonably accurate methods. $\vec{\omega}$ Bacterial counts by the pour-plate technique and estimates of the white cell excretion per hour or day, while undoubtedly of diagnostic value, are probably unsuitable for use on a wide scale. In an attempt to find more convenient procedures a simplified stroke-plate method of bacterial counting and a simplified quantitative white cell count method were devised and applied to over 1,000今 mid-stream urine samples from 398 patients. Good correlation was obtained between the simpler stroke-plate method of bacterial counting and the more time-consuming pour-plate method. The quantitative white cell procedure was a much more sensitive index of pyuria than wet-film microscopy, and comparison with the bacterial count results showed that it gave a useful indication of ${ }^{\omega}$ urinary infection. It is suggested that a quantitative bacterial count should replace non-quantitativeo culture methods when urinary infection is suspected and that the quantitative white cell count $\frac{3}{\bar{D}}$ should be performed as a routine part of the initial clinical and laboratory assessment of all patients, followed by a bacterial count if pyuria is revealed. Experience has shown that routine urine $\mathbb{D}$ microscopy by a precise method leads to the detection of many cases of occult urinary infection.

Estimates of the incidence of pyelonephritis on the basis of necropsy evidence have ranged from $6.18 \%$ (Brod, 1956) to $20 \%$ (Rhoads, Billings, and O'Conor, 1952). Many of these cases are undiagnosed, probably because obvious symptoms of urinary tract inflammation, such as dysuria and frequency of micturition, are often absent or slight, particularly if the infection is chronic. Thus, Kleeman, Hewitt, and Guze (1960) report that out of 629 cases of significant pyelonephritis seen at necropsy in a five-year period, only $104(16.6 \%)$ were diagnosed clinically, although they stress that retrospective study of the case records indicated that there was suggestive information in $70 \%$ of all cases.

The use of bacterial counts (Kass, 1955, 1956, 1957) and of quantitative cell counts by the Addis technique (Lippman, 1957) or the method of Houghton and Pears (1957) are definite advances but these techniques are still not widely employed in this country and the view has been expressed (Annotation, 1961) that they are perhaps too time-consuming for routine use and that what is required is a simpler yet

Received for publication 13 July 1962. reasonably accurate screening procedure. We have been engaged for more than two years in a study of urinary tract infection employing mid-stream urine? specimens and simplified quantitative assessments ofo pyuria and bacteriuria, in addition to conventional bacteriological methods of urine study. Over 1,0008 urine samples from 398 patients have been studied $₹$ and we are of the opinion that these simplifiedo quantitative techniques are of definite value in the diagnosis of pyelonephritis and that they are suitable for routine use.

\section{MATERIAL AND METHODS}

The patients were either in the medical wards of the hospital or were attending a special out-patient clinic for medical diseases of the kidney. The age and sex of theo patients is shown in Figure 1. The majority were womeno $(84 \%)$ and the mean age was 39 years.

METHOD OF URINE COLLECTION In women, after pre-0 liminary cleansing of the vulva with sterile saline, a mid. stream specimen of urine was passed directly into a sterile्ले Universal container of $30 \mathrm{ml}$. capacity or, if this seemed 2 likely to present difficulties to the patient, it was collected 


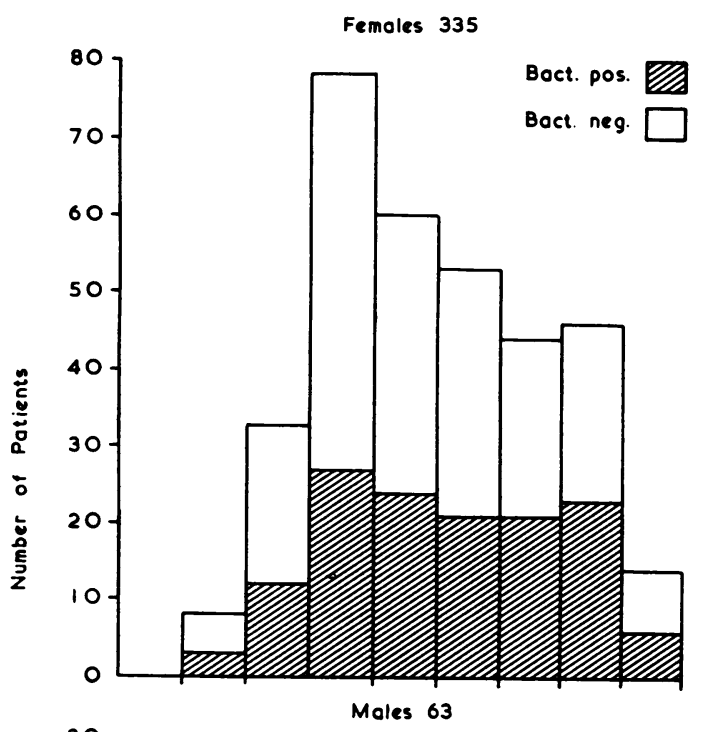

the cellular excretion using the Addis count (Lippman, 1957). This technique, and the modification of it described by Houghton and Pears (1957), utilized a specimen from urine passed after a measured period of time and both Lippman (1957) and Houghton and Pears (1957) recommended that in women the urine be collected by catheter. For reasons which have been cogently expressed by Beeson (1958) we now prefer to use midstream specimens and the technique of cell counts was modified as follows.

A standard $10 \mathrm{ml}$. volume of the mid-stream specimen is centrifuged in a graduated tube at 3,000 r.p.m. for three minutes, $9 \frac{1}{2} \mathrm{ml}$. of the supernatant urine is pipetted off and tested for protein, and the sediment is resuspended in the remaining $\frac{1}{2} \mathrm{ml}$. of urine by vigorous mixing with a Pasteur pipette. A drop of the suspension is used to fill a Neubauer counting chamber and the white cells in the

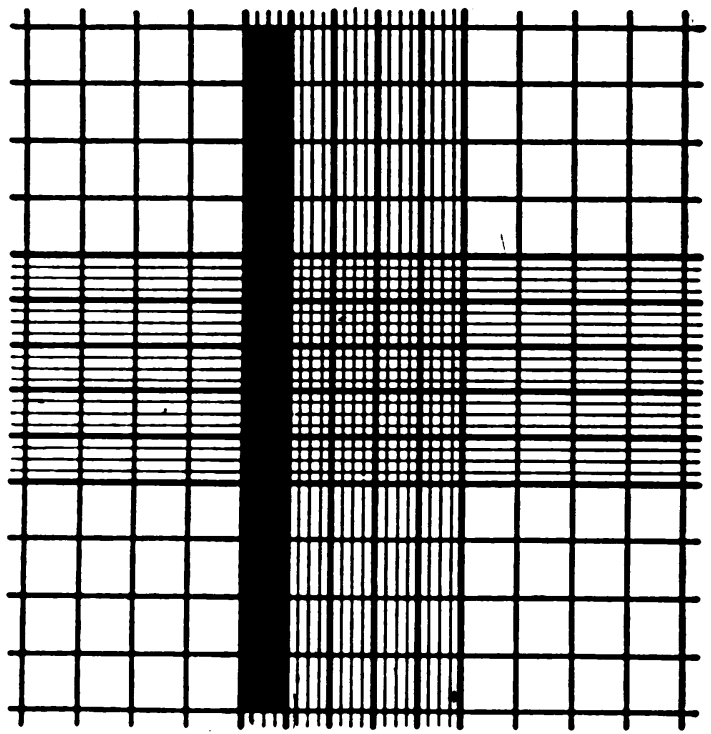

initially in a wider-mouthed sterile receptacle (e.g., a $50-\mathrm{ml}$. glass beaker). Similar methods of mid-stream techniques have been described by Turner (1961) in pregnant women. The nursing staff have little difficulty in obtaining satisfactory samples if the patient's bladder is adequately full, e.g., after three or four hours; if not, epithelial cells and organisms are insufficiently flushed away by the first part of the urine stream, and contamination by urethral commensals is likely; moreover the number of pathogenic organisms may be low because of inadequate pooling of the urine (Kass, 1955). Attention to bladder content is most important in out-patients many of whom, unless advised otherwise, micturate just before attending hospital. Mid-stream urine samples were also employed in the male patients.

The urine sample was examined within one hour or, when this was impracticable, it was refrigerated at $4^{\circ} \mathrm{C}$. until it could be examined, since at room temperature any bacteria present may multiply rapidly. We have ascertained that refrigeration up to 24 hours does not affect the bacterial count but if such delay is envisaged it is desirable to perform the cell count within a few hours. The well-mixed urine sample was divided into two parts, one of which was used for the quantitative cell count and the other for the bacteriological studies. The results of the procedures were compared only after completion of each batch of samples.

METHOD OF QUANTITATIVE CELL COUNT Before deciding on mid-stream urine samples in women we determined

FIG. 2. Ruled area of modified Neubauer counting chamber. The black area is the unit area for cells.

area shown in Fig. 2 are counted. If the count is low (10 or less) three or four such areas are counted and the mean estimated. In order to keep the procedure as simple as possible, the multiplication factor (833) required to express the result as cells per millilitre was not employed and the white cell count is referred to simply as cells per measured area.

METHODS OF BACTERIOLOGICAL STUDY Bacterial counts were performed initially by a pour-plate method using a 1 in 10,000 dilution of urine in sterile water. One millilitre of the diluted urine was mixed with nutrient agar and $1 \mathrm{ml}$. with MacConkey no. 2 agar (Oxoid). Both plates were incubated at $37^{\circ} \mathrm{C}$. and examined after 24,48 , and 72 hours. Each colony represented 10,000 organisms per millilitre of uncentrifuged urine. In practice it was found that the equipment (Fig. 3a) and time required for this method made it unsuitable for convenient use in a busy 

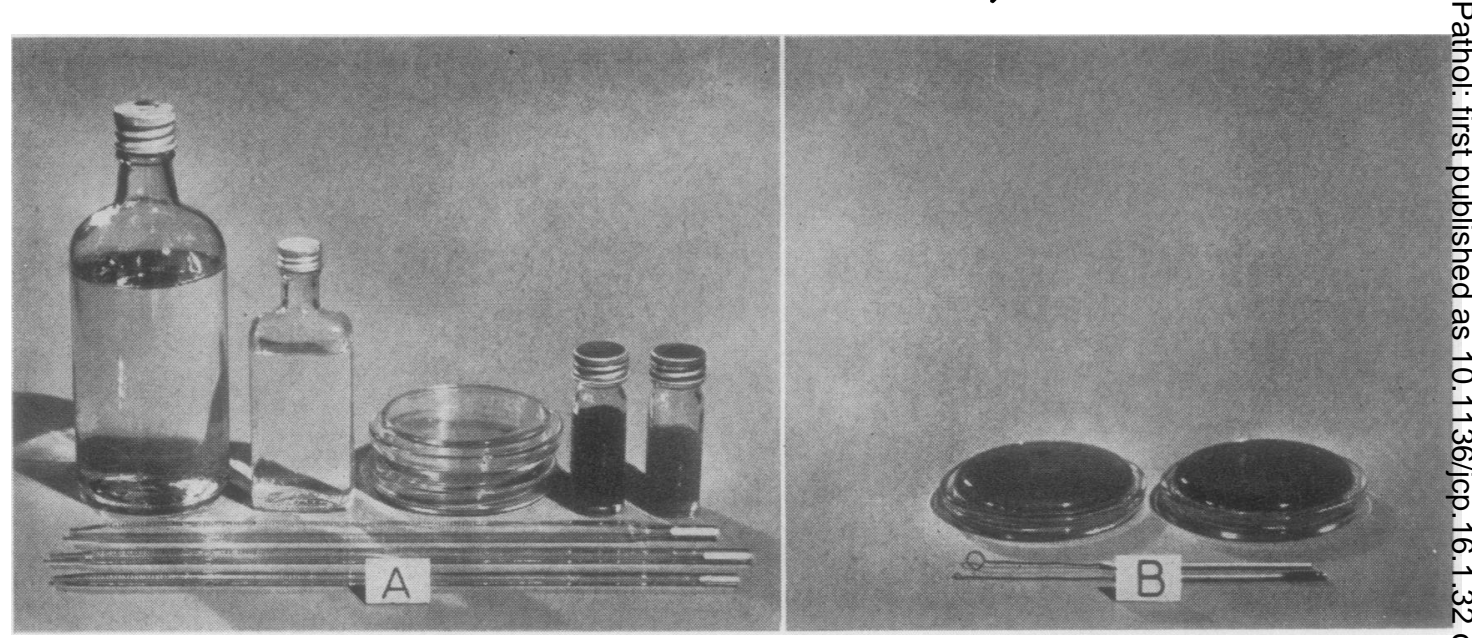

FIG. 3. A Sterile equipment required for a pour-plate colony coint on a single urine specimen; B equipment require $\frac{a}{3}$ for stroke-plate colony count.

bacteriology laboratory and, accordingly, the following simplified stroke-plate method was developed. The essential part of the equipment (Fig. 3b) is a bacteriological loop, delivering a known volume, which is used to inoculate the well-mixed uncentrifuged urine directly on to a blood agar and a MacConkey plate. The loopful was plated across one edge of the plate to a width of $1 \mathrm{~cm}$. using 20 strokes. Using a second sterile loop an area $1 \mathrm{~cm}$. wide was plated $2 \mathrm{~cm}$. from the end of and at right angles to the original inoculation. This procedure was repeated twice to give a box-like inoculated plate with each side $1 \mathrm{~cm}$. thick (Fig. 4). After incubation the number of colonies was counted and multiplied by the reciprocal of the loop's volume to give the number of organisms per

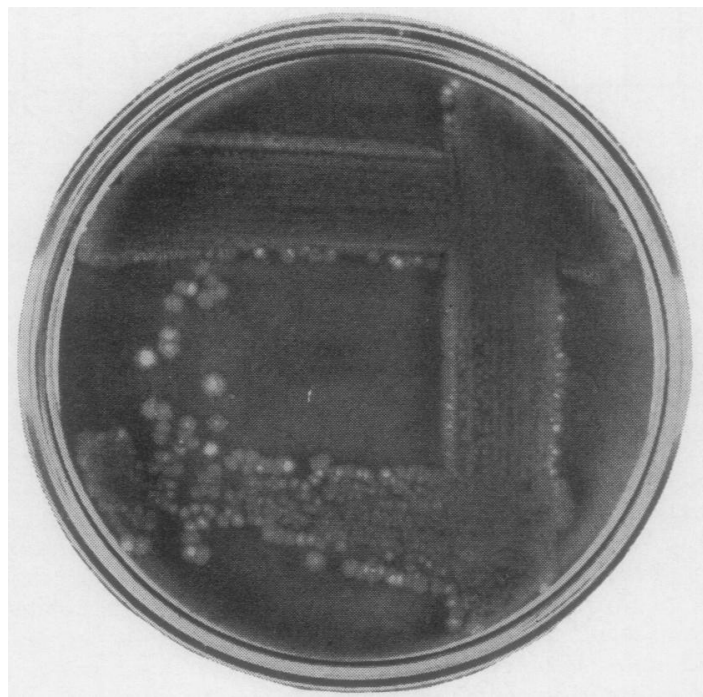

FIG. 4. Stroke-plate showing areas of inoculation (high bacterial count specimen). millilitre of urine. Growth was noted as,,$++++++\frac{2}{q}$ or ++++ , depending on whether one, two, three, of four sides of the inoculated area showed colonies.

Gram-stained films were made of a measured loopfu of uncentrifuged urine and of an uncalibrated loopful of centrifuged deposit and 50 fields examined under the oil immersion objective. Two loopfuls of the centrifuges deposit were covered with a standard $\frac{7}{8} \times \frac{7}{8}$ in. cover sli $\vec{B}$ and the number of white cells per 20 high-power field (H.P.F.) estimated by examination under the $1 / 6$ objec $\Phi$ tive. All centrifuged deposits were from $10 \mathrm{ml}$. of urine spun at 2,500 r.p.m. for five minutes.

\section{RESULTS AND INTERPRETATION}

Following the work of Kass (1956) on the significance. of bacterial counts, the urine samples were divided into high, intermediate, and low bacterial count groups:-

1 Bacterial count over 100,000 organisms per $\mathrm{ml} \frac{}{3}$ meant infection present; 2 bacterial count $10,000_{0}$ 100,000 organisms per $\mathrm{ml}$. meant infection doubtful developing, or suppressed; 3 bacterial count lest than 10,000 organisms per $\mathrm{ml}$. meant infection absent

Of the 1,078 specimens, $830(77 \%)$ were in the low or negative group, $99(9 \%)$ in the intermediate ors doubtful group, and $149(14 \%)$ in the high ofv positive group (Fig. 5).

COMPARISON BETWEEN POUR-PLATE AND STROKE-PLATE METHODS FOR BACTERIAL COUNTS In 165 specimen\& a direct comparison was made between the pourplate method and the stroke-plate method (Table I) There was very good correlation between the twळे techniques in the high and low bacterial counts. 0 the 19 specimens classified as 'intermediate' by the pour-plate method, four were in the 'high' group bf 


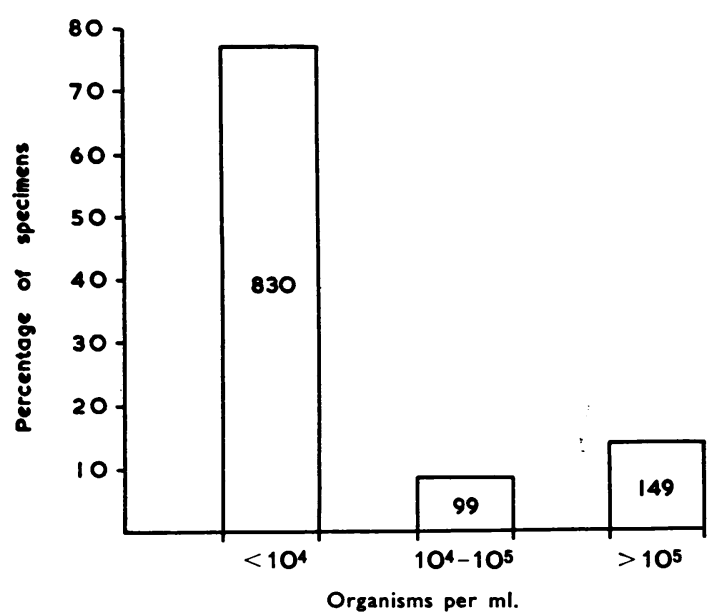

FIG. 5. Distribution of 1,078 urine specimens into low, intermediate, and high bacterial count groups.

TABLE I

CORRELATION BETWEEN POUR-PLATE AND STROKE-PLATE METHODS OF BACTERIAL COUNTS

\begin{tabular}{llll}
$\begin{array}{l}\text { Pour-plate } \\
\text { Method } \\
\text { (organisms/ml.) }\end{array}$ & $\begin{array}{l}\text { Stroke-plate Method } \\
\text { (organisms/ml.) }\end{array}$ & $\begin{array}{l}\text { Number of } \\
\text { Specimens }\end{array}$ \\
\cline { 2 - 3 } & $\begin{array}{l}\text { More than } 10,000 \text { to } \\
100,000\end{array} 100,000$ & $\begin{array}{l}\text { Less than } \\
10,000\end{array}$ & \\
\hline
\end{tabular}

\section{More than}

100,000

10,000 to

100,000

Less than

10,000

$\begin{array}{rllr}100 \% & - & - & 37 \\ 21 \% & 79 \% & - & 19 \\ 2 \% & 6 \% & 92 \% & 109\end{array}$

the stroke-plate method; three of these, however, had a bacteriuria of more than 50,000 organisms per $\mathrm{ml}$. by the pour-plate method, while the other was from a patient on tetracycline therapy. The agreement between the two techniques is, in our opinion, sufficiently close to allow the much simpler strokeplate method to be used for routine bacterial counts and it alone was employed for the remaining samples in this study.

The correlation between the bacterial count and the number of sides of the stroke-plate showing growth is given in Table II. It will be seen that $85.8 \%$ of specimens with more than 100,000 organisms per millilitre of urine produced growth on three or four sides of the plate; conversely $87 \%$ of plates with growth on three or four sides were inoculated with urine containing more than 100,000 organisms per millilitre. Indeed $73 \%$ of plates with growth on two, three, or four sides had bacterial counts of more than 50,000 organisms per millilitre.

CORRELATION BETWEEN BACTERIAL COUNTS AND QUANTITATIVE CELL COUNTS A direct comparison
TABLE II

CORRELATION BETWEEN BACTERIAL COUNT AND NUMBER OF AREAS OF STROKE-PLATE SHOWING GROWTH

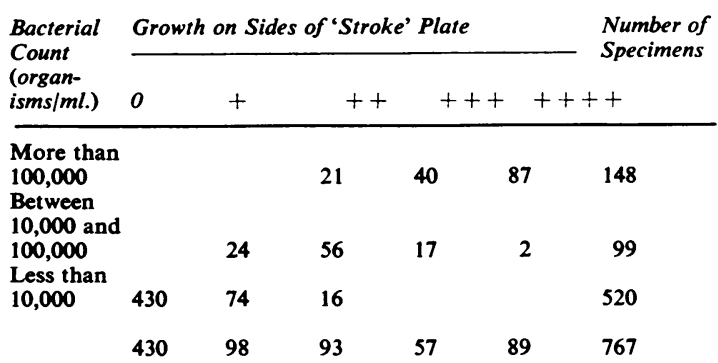

was made of these two counts in 931 specimens. Quantitative cell and bacterial counts were performed on a further 103 samples of urine from 56 patients with glomerulonephritis, but these are excluded from this comparison since it was felt that the cell counts would be affected by the glomerular lesion. In Fig. 6, the specimens are divided into three groups-negative, doubtful, and positive-depending on the bacterial count. In the bacteriologically negative group the cell count was very low (in the bulk of samples $75.5 \%$ contained 10 or fewer cells per measured area), in the bacteriologically doubtful group there was a similar although not quite so marked pattern, while in the positive group the pattern was largely reversed. Table III shows the correlation between pyuria and bacteriuria using 10 cells per measured area as a level of possible significance. Of the high bacterial count specimens, $87 \cdot 3 \%$

TABLE III

CORRELATION BETWEEN PYURIA AND BACTERIURIA USING THE LEVEL OF 10 OR LESS CELLS PER MEASURED AREA

\begin{tabular}{llcc}
$\begin{array}{l}\text { Bacterial Count } \\
\text { (organisms/ml.) }\end{array}$ & \multicolumn{2}{c}{ Quantitative White Cell Count (\%) } & $\begin{array}{l}\text { Number } \\
\text { Specimen }\end{array}$ \\
\cline { 2 - 3 } & 10 and Less & More than 10 & \\
\hline $\begin{array}{l}\text { More than } \\
100,000\end{array}$ & 12.7 & $87 \cdot 3$ & 142 \\
$\begin{array}{l}10,000 \text { to } \\
100,000\end{array}$ & 60 & 40 & 86 \\
$\begin{array}{l}\text { Less than } \\
10,000\end{array}$ & 75.5 & 24.5 & 703
\end{tabular}

had cell counts of more than 10 per measured area, while of the low bacterial count specimens $75.5 \%$ had cell counts of 10 or less per measured area; of the smaller intermediate bacterial count group, $60 \%$ had 10 or fewer cells per measured area and $40 \%$ had higher cell counts.

COMPARISON BETWEEN QUANTITATIVE CELL COUNTS AND WET FILM EXAMINATION A direct comparison was made of these two techniques in 1,002 urine samples (Table IV). As might be expected, both techniques revealed the gross degrees of pyuria. If, how- 

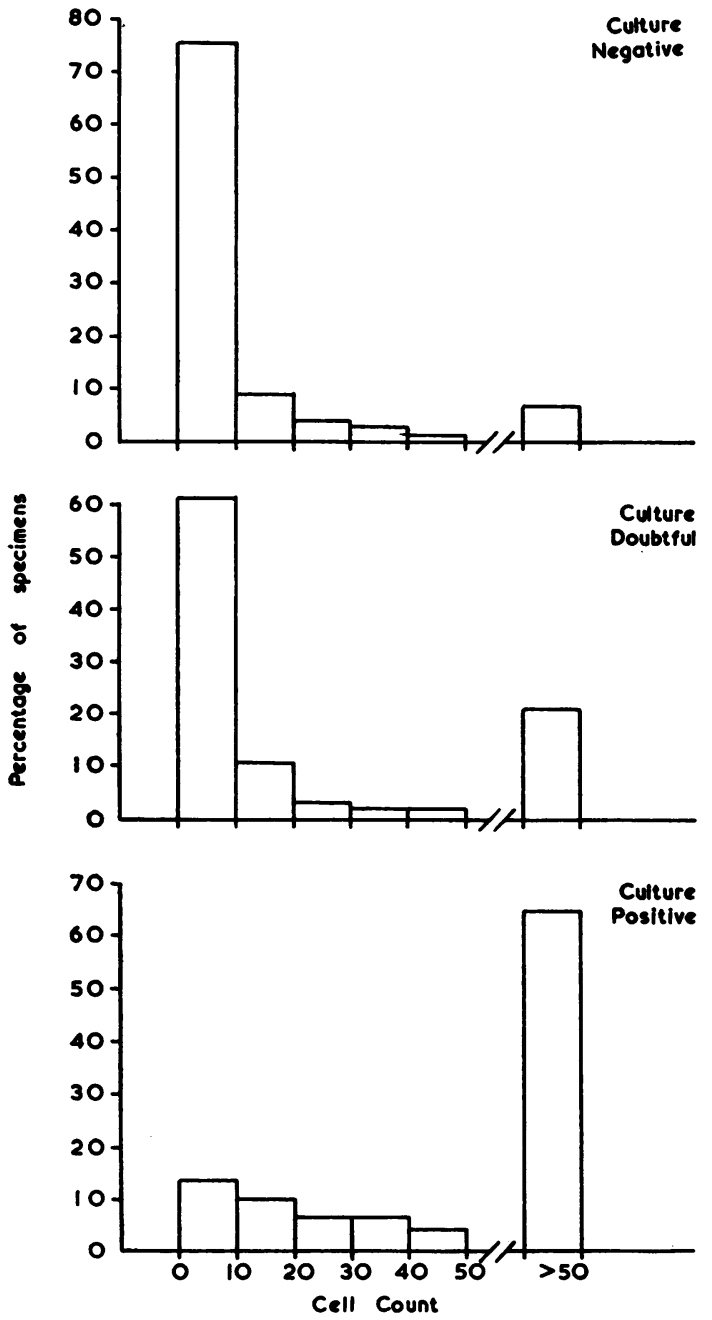

FIG. 6. Distribution of cell counts in negative, intermediate, and positive bacterial count groups. ever, the usual criterion of 5 or more cells per H.P.F.

i.e., more than 100 per 20 H.P.F., on wet-filmexamination is taken as indicative of infection it wil厙 be seen that $65 \%$ of specimens with lesser degrees of pyuria had in fact white cell chamber counts of more than 10 cells, which is the level we find to have as. high correlation with infection (Table III). Even if the wet film level of significance is lowered to include specimens with more than 10 cells per 20 H.P.F. the discrepancy between the two techniques is still con $\overrightarrow{0}$ siderable $(30 \%)$. There is good overall agreement $(83 \%)$ if 10 or fewer cells for the chamber count value is correlated with a value of below 10 cells per 26 . H.P.F. on the wet film and $76 \%$ agreement if this correlation is with less than 100 cells per 20 H.P.F on the wet film.

COMPARISON BETWEEN BACTERIAL COUNTS AND ASSESSMENTS OF BACTERIAL FREQUENCY IN GRAM $=$ STAINED FILMS Both the centrifuged and uncentrio fuged film assessments are included in Table $V \vec{c}$ There is close correlation between the two films in the high counts, $93 \%$ of the centrifuged and $80 \%$ of the uncentrifuged films showing the presence of pathogens in the 50 fields counted. In the low bacterial counts, if the films showing vaginal come mensals only are excluded, the correlation is again close; in $78 \%$ of the centrifuged films and $99 \%$ of the uncentrifuged films no organisms were noted. In the intermediate group the films are less useful fo? estimating the concentration of organisms.

INCIDENCE OF SPECIES ISOLATED In this survey 13 ? patients had bacterial counts of more than 100,000 . organisms per millilitre of urine. From 123 patients single species were isolated; of these 110 were Escho coli, five Proteus mirabilis, three Paracolon bacillus? two Staph. albus (coagulase negative), one eacts Klebsiella (Aer. aerogenes) and Ps. aeruginosa. Of the nine patients with two species, four had Esch. colob

TABLE IV

CORRELATION BETWEEN ASSESSMENT OF PYURIA BY QUANTITATIVE CELL COUNT AND WET FILM ESTIMATION

\begin{tabular}{|c|c|c|c|c|c|c|}
\hline \multirow[t]{2}{*}{$\begin{array}{l}\text { Quantitative } \\
\text { White Cell Count }\end{array}$} & \multicolumn{5}{|c|}{$\begin{array}{l}\text { Wet Film Estimation } \\
\text { (white cells per } 20 \text { H.P.F.) }\end{array}$} & \multirow[t]{2}{*}{$\begin{array}{l}\text { Number of } \\
\text { Specimens }\end{array}$} \\
\hline & 0 & $1-9$ & $10-99$ & $100-250$ & $>250$ & \\
\hline 10 and less & $\begin{array}{l}314 \\
49 \cdot 6 \%\end{array}$ & $\begin{array}{l}258 \\
40 \cdot 7 \%\end{array}$ & $\begin{array}{l}59 \\
9 \cdot 3 \%\end{array}$ & $\begin{array}{l}2 \\
0.3 \%\end{array}$ & - & 633 \\
\hline More than 10 & $\begin{array}{r}22 \\
5.9 \% \\
30 \% \\
\leftarrow-\end{array}$ & $\begin{array}{l}92 \\
24.9 \% \\
65 \%\end{array}$ & $\begin{array}{l}128 \\
34 \cdot 7 \%\end{array}$ & $\begin{array}{l}78 \\
21 \cdot 1 \%\end{array}$ & $\begin{array}{l}49 \\
13.3 \%\end{array}$ & 369 \\
\hline
\end{tabular}


TABLE V

CORRELATION BETWEEN BACTERIAL COUNT AND GRAM FILMS

Bacterial Count
(organisms/ml.)

Centrifuged Deposit Film

Uncentrifuged Film

Positive Negative

Number of

Positive

Negative

Number of

140

More than 100,000

10,000 to 100,000

130
37

10

40

63

16

Less than 10,000

360

333

693

12

166
(164)

50

(268)

$333 \quad 693$

222

388

Figures in parentheses are films in which the organisms are vaginal commensals.

with Strep. faecalis, three had Esch. coli with Proteus mirabilis, and two had Paracolon bacillus and Strep. faecalisisolated. Four of the five patients with Proteus infections had underlying urinary tract lesions.

\section{DISCUSSION}

It is now generally accepted that although pyelonephritis is a common disease, it escapes clinical notice in a high proportion of patients who may have no symptoms obviously referable to the urinary tract (Loopuyt, 1946; Brod, 1956; Kass, 1956; MacDonald, Levitin, Mallory, and Kass, 1957; Jackson, Poirier, and Grieble, 1957; Kleeman, Hewitt, and Guze, 1960). The present unsatisfactory diagnostic position would be much improved by widespread screening of patients by methods which are simple and reasonably accurate. Bacterial counts (Kass, 1955, 1956, 1957) and estimates of white cell excretion (Lippman, 1957; Houghton and Pears, 1957) in the urine are undoubtedly of diagnostic help but it may be questioned whether the techniques, in their original form, are suitable for general use. The pour-plate method of bacterial counting may be too time-consuming for adoption in many hospital laboratories and accurate determination of the urinary white cell excretion per hour presents difficulties in out-patient departments. The simplified stroke-plate bacterial count and quantitative white cell count techniques described in this paper do not have these disadvantages and we suggest that they may be suitable for widespread application.

THE URINE SAMPLE The use of mid-stream, or cleanvoided specimens of urine from women has obviated the need for diagnostic catheterization with its attendant dangers (Marple, 1941; Kass, 1956; Beeson, 1958; Kaitz and Williams, 1960; Brumfitt, Davies, and Rosser, 1961) and the procedure is now widely, although not universally, employed. The correlation between catheter and mid-stream specimens of urine has been extensively studied (Monzon, Ory, Dobson, Carter, and Yow, 1958; Riley, 1958; Pryles and Steg, 1959; Clarke, 1960) and with correct technique close agreement has been reached. Contamination from the urethra and vulva may occur due to poor technique but can usually be recognized by the presence of squamous epithelial cells and closely related diphtheroids, Döderlein's bacilli, or micrococci in the Gram-stained film.

Although urine, and in particular pyelonephritic urine, is a medium in which the lag-phase is short (Jackson and Grieble, 1957) significant multiplication does not occur at room temperature within an hour and we would agree that when the specimen cannot be delivered to the laboratory within this time it should be stored at $4^{\circ} \mathrm{C}$.

BACTERIAL COUNTS The three levels of bacteriuria described by Kass (1956) are now established indications of the probability of urinary infection and our findings are in keeping with his views. We would agree that a quantitative bacterial count is desirable in diagnostic bacteriological studies on the urine. Where non-quantitative methods are used it is common to employ such phrases as 'moderate', 'light', or 'scanty' growth and the clinician, if not the bacteriologist, may be in considerable doubt as to whether urinary infection is present or not. The use of quantitative methods gives much more positive guidance as to the presence or absence of infection and minimizes observer error. We accept that if the bacterial count is over 100,000 organisms per millilitre infection is present, if it is below 10,000 organisms per millilitre infection is absent, while if the count is in the intermediate zone $(10,000$ to 100,000 organisms per millilitre) suspicion of infection should be aroused and either a further urine sample studied or, if this is not readily available, treatment should be given. It is in this intermediate group that bacterial counts are most valuable since the results by other methods of study are so equivocal.

As regards the method of quantitative bacterial count we submit that the pour-plate colony count is impractical for a busy laboratory and that the simplified method using a calibrated loop is preferable. Our results show satisfactory correlation between the loop method and the pour-plate method and this is 
in agreement with similar studies reported independently by Hoeprich (1960) and O'Sullivan, FitzGerald, Meynell, and Malins (1960). These authors, however, spread the inoculum over the surface of half the plate (Hoeprich) or all the plate (O'Sullivan et al.). We consider that the box-like inoculum provides not only an accurate method of counting the colonies, but also a rapid visual indication of higher counts by reference to the number of sides of the box showing growth.

QUANTITATIVE CELL COUNTS The comparison of the results of white cell counts in the urine samples with the bacterial count studies suggests that the quantitative cell count technique described may usefully contribute to the detection of patients with asymptomatic urinary infection. The correlation between the white cell level in the urine and the degree of bacteriuria is closer than in previously reported studies (MacDonald et al., 1957; Jackson, Grieble, and Knudsen, 1958; Kass, 1957; and Rengarts, 1960) in which the general impression was that pyuria was not a reliable indication of urinary infection. We feel that this difference of opinion is due first to the use of the variable and relatively inaccurate method of the ordinary wet film technique, and secondly to the use of 5 or more cells per H.P.F. as the indication of pyuria; in the quantitative cell count method described here, a level of 10 cells per measured area corresponds to one-tenth of the level of significance taken in the studies quoted above.

GRAM-STAINED FILM The Gram-stained film, both centrifuged and uncentrifuged, gave reasonable correlation in the high and low bacterial count groups, but was of less use in the intermediate group. The Gram-stained film would also identify vaginal commensals and may thus help as a pre-culture guide along with the chamber count where there is urgency in reaching a diagnosis, e.g., in helping to differentiate acute pyelonephritis from acute appendicitis.

SUGGESTED USE OF BACTERIAL AND WHITE CELL COUNT METHODS On the basis of our experience in looking for patients with infection of the renal tract, we would suggest that the two relatively simple quantitative methods described here may most usefully be employed as follows.

Where there is clinical suspicion of renal tract infection, either on the basis of present symptoms or past history, the bacterial count, preferably along with the white cell count, should be performed in preference to non-quantitative culture methods; where the result is negative or inconclusive and clinical suspicion of infection is still present, then the $\frac{0}{2}$ tests should be repeated on further mid-stream urine 으․ samples, since bacteria may be present only inter- $\vec{F}$ : mittently in the urine. Analogy may be made with the standard practice of performing repeat examina- $\frac{C}{0}$ tions of sputum if pulmonary tuberculosis is being $\frac{\bar{\sigma}}{\bar{m}}$ considered, or repeat blood cultures if subacute $\vec{\Phi}$ bacterial endocarditis is suspected. In many cases of $\bigcirc$ course, other methods of investigation such asis pyelography would also be required.

If there is no clinical suspicion of renal tract infection we perform the simplified white cell count $\vec{\omega}$ along with chemical urine analysis, estimation of $\mathrm{Hb}, \stackrel{\widehat{\circ}}{\mathrm{O}}$ E.S.R., etc., as part of the basic diagnostic study? of all patients admitted to the medical unit. The test $\vec{\sigma}$ can be done in a few minutes in the ward side-room:or ward laboratory by the house physician or registrar, and is followed by a bacterial count if으 pyuria is revealed. It is our experience that thispractice leads to the detection of a substantial number of completely asymptomatic cases of renal? tract infection which would otherwise have been undiagnosed.

We wish to express our appreciation to Professor E. M. McGirr and Dr. J. C. J. Ives for facilities and encourage-ment throughout this study and to thank Mr. W. McCormick for technical assistance.

\section{REFERENCES}

Annotation. (1961). Lancet, 2, 1077.

Beeson, P. B. (1958). Amer. J. Med., 24, 1.

Brod, J. (1956). Lancet, 1, 973.

Brumfitt, W., Davies, B. I., and Rosser, E. ap I. (1961). Lancet, 2, 1059

Clarke, S. H. C. (1960). Brit. med. J., 2, 1491.

Hoeprich, P. D. (1960). J. Lab. clin. Med., 56, 899.

Houghton, B. J., and Pears, M. A. (1957). Brit. med. J., 1, 622.

Jackson, G. G., and Grieble, H. G. (1957). A.M.A. Arch. intern. Med.

100, 692.
Poirier, K. P., and Grieble, H. G. (1957). Ann. intern. Med 47, 1165.

_, Grieble, H. G., and Knudsen, K. B. (1958). J. Amer. med. Ass. $166,14$.

Kaitz, A. L., and Williams, E. J. (1960). New Engl. J. Med., 262, 425음

Kass, E. H. (1955). Amer. J. Med., 18, 764.

(1956). Trans. Ass. Amer. Phycns, 69, 56.

- (1957). A.M.A. Arch. intern. Med., 100, 709.

Kleeman, C. R., Hewitt, W. L., and Guze, L. B. (1960). Medicine (Baltimore), 39, 3.

Lippman, R. W. (1957). Urine and the Urinary Sediment, 2nd ed: Thomas, Springfield, Illinois.

Loopuyt, L. (1946). Acta med. scand., 125, 245.
MacDonald, R. A., Levitin, H., Mallory, G. K., and Kass, E. HW (1957). New Engl. J. Med., 256, 915.

Marple, C. D. (1941). Ann. intern. Med., 14, 2220.

Monzon, O. T., Ory, E. M., Dobson, H. L., Carter, E., and Yoik E. M. (1958). New Engl. J. Med., 259, 764.

O'Sullivan, D. J., FitzGerald, M. G., Meynell, M. J., and Malinş J. M. (1960) J clin. Path., 13, 527.

Pryles, C. V., and Steg, N. L. (1959). Pediatrics, 23, 441.

Rengarts, R. T. (1960). Amer. J. med. Sci., 239, 159.

Rhoads, P. S., Billings, C. E., and O'Conor, V. J. (1952). J. Ame med. Ass., 148, 165.

Riley, H. D. (1958). J. Lab. clin. Med., 52, 840.

Turner, Grace C. (1961). Lancet, 2, 1062. 